University of Nebraska - Lincoln

DigitalCommons@University of Nebraska - Lincoln

Agronomy \& Horticulture - Faculty Publications

Agronomy and Horticulture Department

1988

\title{
Colorimetric Determination of Cyanide in Enzyme-Hydrolyzed Extracts of Dried Sorghum Leaves
}

\author{
Francis A. Haskins \\ University of Nebraska-Lincoln, fhaskins@neb.rr.com \\ Herman J. Gorz \\ University of Nebraska-Lincoln \\ Robert M. Hill \\ University of Nebraska-Lincoln
}

Follow this and additional works at: https://digitalcommons.unl.edu/agronomyfacpub

Part of the Plant Sciences Commons

Haskins, Francis A.; Gorz, Herman J.; and Hill, Robert M., "Colorimetric Determination of Cyanide in Enzyme-Hydrolyzed Extracts of Dried Sorghum Leaves" (1988). Agronomy \& Horticulture -- Faculty Publications. 179.

https://digitalcommons.unl.edu/agronomyfacpub/179

This Article is brought to you for free and open access by the Agronomy and Horticulture Department at DigitalCommons@University of Nebraska - Lincoln. It has been accepted for inclusion in Agronomy \& Horticulture -Faculty Publications by an authorized administrator of DigitalCommons@University of Nebraska - Lincoln. 


\title{
Colorimetric Determination of Cyanide in Enzyme-Hydrolyzed Extracts of Dried Sorghum Leaves
}

\author{
Francis A. Haskins,* Herman J. Gorz, and Robert M. Hill
}

\begin{abstract}
The purpose of this study was to develop a simple and effective procedure for assaying large numbers of sorghum leaf samples for their potential to release cyanide. The procedure involves drying the tissue at $75^{\circ} \mathrm{C}$ (this was accomplished without loss of the cyanogenic glucoside dhurrin), grinding the dry tissue, extracting with water, digesting the extract with an almond meal extract to release cyanide, and determining cyanide in the digest colorimetrically. Results obtained were comparable to those based on distillation of digested samples and potentiometric determination of cyanide in the distillates. The equipment and supplies required for the procedure are relatively inexpensive, and a skilled technician can conveniently assay 70-80 samples/day.
\end{abstract}

Cyanide occurs in the leaves of sudangrass [Sorghum bicolor (L.) Moench] and sorghum (also S. bicolor) plants as the cyanogenic glucoside dhurrin [ $p$-hydroxy- $(S)$ mandelonitrile $\beta$-D-glucopyranoside]. Degradation of dhurrin yields equimolar amounts of $\mathrm{HCN}$, glucose, and $p$-hydroxybenzaldehyde ( $p$-HB). One of the objectives of sudangrass and sorghum breeding programs is reduction in the level of dhurrin and thus in the possibility that cyanide released from the plant tissues will be harmful to consuming livestock. Plant-breeding and genetics programs typically require the examination of large numbers of individual plants. The HCN potentials (HCN-p) of large numbers of young sorghum seedlings can be assayed conveniently by autoclaving seedling leaves in water to extract and hydrolyze the dhurrin, diluting the extract in alkali, and reading the absorbance at $330 \mathrm{~nm}$, the absorbance maximum of $p$-HB in basic solution, as described by Gorz et al. (1977). However, this simple procedure is not satisfactory for mature sorghum leaves (Haskins et al., 1984), and assays of mature leaves are required when measurements on the forage actually consumed by animals are needed. Blaedel et al. (1971) described an assay for cyanide in sudangrass forage in which emulsin was used to hydrolyze dhurrin, and cyanide in the hydrolysate was then determined directly with a cyanide-selective electrode. In our experience, however, the electrode was affected

Departments of Agronomy (F.A.H., H.J.G.) and Biochemistry (R.M.H.), University of Nebraska, Lincoln, Nebraska 68583. adversely by constituents of the crude extracts; equilibration was slow, and misleading results were sometimes obtained.

The objective of this study was to adapt published procedures to provide for assay of the HCN-p of large numbers of samples with relatively inexpensive equipment and supplies. Specific information was sought on (1) the effect of tissue drying on $\mathrm{HCN}-\mathrm{p}$, (2) the feasibility of using an extract of almond meal to hydrolyze dhurrin in crude extracts of sorghum leaves, and (3) the suitability of the colorimetric procedure of Lambert et al. (1975) for determination of cyanide in these hydrolyzed extracts.

\section{MATERIALS AND METHODS}

Reagents. Succinimide, $N$-chlorosuccinimide, and barbituric acid for use in the procedure of Lambert et al. (1975) were obtained from Sigma Chemical Co., as was defatted almond meal. Other chemicals were obtained from customary sources.

Enzyme Preparation. Defatted almond meal was suspended in water $(8 \mathrm{mg} / \mathrm{mL})$, and the mixture was allowed to stand at room temperature for $3 \mathrm{~h}$ with occasional gentle shaking, after which it was filtered (Whatman No. 1 filter paper). The filtrate was used as the enzyme preparation. Such filtrates could be stored at $4{ }^{\circ} \mathrm{C}$ for at least 2 days without apparent loss in activity.

Plant Material. Week-old seedlings were grown in pans of a soil mixture in growth chambers at $27^{\circ} \mathrm{C}$ under continuous cool white fluorescent light at about 150 $\mu \mathrm{mol} / \mathrm{m}^{2}$ per $\mathrm{s}$, and shoots were excised just above the soil surface. For older plants from the field or greenhouse, 
blades of upper leaves were excised and midribs were removed and discarded. Samples (usually less than $10 \mathrm{~g}$ ) of the fresh tissue were placed in small baskets made of plastic screen and were oven-dried at $75^{\circ} \mathrm{C}$ for about $3 \mathrm{~h}$. The dry tissue was ground through a $1-\mathrm{mm}$ screen and stored in tightly capped plastic vials at $-18^{\circ} \mathrm{C}$ prior to extraction for assay. The ground tissue was extracted as previously described (Gorz et al., 1986) by suspending weighed portions in water (usually $5 \mathrm{mg} / \mathrm{mL}$ ) and shaking on a Gyrotory shaker for $2-3 \mathrm{~h}$ at room temperature. Suspensions were then filtered through Whatman No. 1 filter paper, and portions of the filtrates were used for assay.

Assay Procedures. Colorimetric Assay. The following procedure reflects the results of numerous preliminary experiments in which concentrations of enzyme preparation and plant extract and duration of digestion were varied. To $1 \mathrm{~mL}$ of tissue extract in a $20 \times 150 \mathrm{~mm}$ test tube was added $1 \mathrm{~mL}$ of enzyme preparation, and the tube was capped with Parafilm and allowed to stand for 1.25 $h$ at room temperature. The cap was then removed, and $8 \mathrm{~mL}$ of $0.1 \mathrm{M} \mathrm{NaOH}$ was added immediately. This basic solution was assayed for cyanide by the procedure of Lambert et al. (1975) as modified in the laboratory of Dr. E. E. Conn, University of California-Davis (personal communication). To $1 \mathrm{~mL}$ of the basic solution was added $0.5 \mathrm{~mL}$ of $1 \mathrm{M}$ acetic acid followed by $5 \mathrm{~mL}$ of a solution containing $2.5 \mathrm{~g}$ of succinimide and $0.25 \mathrm{~g}$ of $\mathrm{N}$-chlorosuccinimide in $1 \mathrm{~L}$ of water. A $1-\mathrm{mL}$ portion of a solution consisting of $6 \mathrm{~g}$ of barbituric acid, $30 \mathrm{~mL}$ of pyridine, and $70 \mathrm{~mL}$ of water was then added, and the tube was shaken vigorously and allowed to stand at room temperature for precisely $20 \mathrm{~min}$. Absorbance at $580 \mathrm{~nm}$ was then read with a Spectronic 20 colorimeter.

Readings were made in sets of 20 or less, with each set including a colorimeter blank $(1 \mathrm{~mL}$ of $0.1 \mathrm{M} \mathrm{NaOH}$ plus the color reagents), an enzyme control ( $1 \mathrm{~mL}$ of enzyme preparation plus $1 \mathrm{~mL}$ of water, digested, diluted, and sampled as indicated above), a standard of $1 \mathrm{~mL}$ of $3 \times$ $10^{-5} \mathrm{M} \mathrm{NaCN}$ plus the color reagents, and up to 17 samples for assay. Various modifications of this procedure, made for purposes of comparison, are indicated in Results and Discussion.

Potentiometric Assay. This procedure was patterned after the AOAC (1945) method for the determination of cyanide in various feeds and foods. A 5 - $\mathrm{mL}$ portion of enzyme preparation was added to $50 \mathrm{~mL}$ of plant extract in a standard Kjeldahl flask. The flask was stoppered and allowed to stand at room temperature for $2 \mathrm{~h}$. The digest was diluted to $400 \mathrm{~mL}$ with water, the diluted digest was boiled, and $\mathrm{HCN}$ in the distillate was trapped in $20 \mathrm{~mL}$ of $1 \mathrm{M} \mathrm{NaOH}$. The distillate was diluted to $200 \mathrm{~mL}$ with water, and cyanide concentration was determined with a cyanide-selective electrode. For some samples, portions of the distillate also were assayed colorimetrically essentially as described above.

\section{RESULTS AND DISCUSSION}

Use of Almond Meal To Enhance Dhurrin Hydrolysis in Homogenates of Fresh Tissue. The AOAC (1945) procedure for assaying cyanogenic glucosides in feeds suggested that addition of small amounts of emulsin may be necessary to release $\mathrm{HCN}$, but quantities of enzyme or tissue were not specified. Easty et al. (1971) and Blaedel et al. (1971) specified the quantities of emulsin (almond $\beta$-glucosidase) used to hydrolyze dhurrin in sudangrass leaf extracts, but their values were in terms of emulsin rather than almond meal. Our comparison utilized seven sets of four 5-g samples of fresh leaves (midribs removed) rep- resenting different stages of development of greenhouseand field-grown plants of the sorghum-sudangrass hybrid Redlan $\times$ Greenleaf and the grain sorghum line N32 (Ross et al., 1980). Each 5-g sample was homogenized in $150 \mathrm{~mL}$ of water. The homogenate was transferred to a Kjeldahl flask with $300 \mathrm{~mL}$ of water, and the flask was sealed. Two of the samples in each set were incubated at room temperature without added almond meal; $200 \mathrm{mg}$ of almond meal was added to each of the other two samples before incubation. After a 2-h incubation, all samples were distilled into alkali and cyanide was determined with the selective electrode. For the seven sets, the ratio of HCN-p based on incubation without almond meal to the value obtained with almond meal digestion was $0.69 \pm 0.04$ (mean $\pm \mathrm{SE}$ ). Endogenous enzymes apparently did not bring about complete hydrolysis of the dhurrin present in the leaf tissue, nor was the distillation process itself sufficient to effect the complete breakdown, even though dhurrin in aqueous solution is heat-labile (Gorz et al., 1977).

The influence of a second digestion with almond meal was investigated by cooling homogenates following the first distillation, introducing an additional $200 \mathrm{mg}$ portion of almond meal, incubating $2 \mathrm{~h}$ at room temperature, and again distilling. In several trials, the amount of cyanide detected following the second digestion and distillation was less than $3 \%$ as great as that from the initial digestion and distillation.

Effect of Drying the Tissue prior to Assay. In this comparison, 5-g portions of fresh leaf tissue and an equivalent amount of tissue that had been oven-dried at $75^{\circ} \mathrm{C}$ (with the quantities used, $2 \mathrm{~h}$ at this temperature was sufficient to dry the tissue) were used. Both fresh and dried samples were homogenized in water, digested with almond meal, and distilled for cyanide determination as described above. A total of 13 comparisons were made, using leaves from Redlan $\times$ Greenleaf and N32 plants of various ages. On the average, $\mathrm{HCN}-\mathrm{p}$ of the dried samples was $1.10(\mathrm{SE}=0.05)$ times as great as that of the corresponding fresh samples. On the basis of these and other (Haskins et al., 1984) results with oven-dried leaves, it appears that leaf tissue can be dried at temperatures of $65-85^{\circ} \mathrm{C}$ with little or no loss in HCN-p. However, drying for $2 \mathrm{~h}$ at $95{ }^{\circ} \mathrm{C}$ resulted in about $20 \%$ loss in HCN-p.

The use of properly dried tissue for HCN-p assay reduces the danger of spoilage during transport and storage of samples. This is especially important when the assay of fresh samples is inconvenient or impossible. An added advantage of drying is that it permits easy grinding of the tissue, thereby improving the uniformity of subsamples drawn for extraction and assay.

Comparison of Colorimetric and Potentiometric Assays. Fifteen dried and ground samples of sorghum leaf tissue, chosen to represent a wide range in $H C N-p$, were subjected to extraction, the extracts were digested with almond meal, and the digests were assayed both colorimetrically and potentiometrically as described in Materials and Methods. Single extracts of each sample were prepared. Duplicate $50-\mathrm{mL}$ portions of each extract were digested and distilled for potentiometric and colorimetric assays of the distillates, and duplicate $1-\mathrm{mL}$ portions of each extract were digested for direct colorimetric assay of the digests. Agreement among the three sets of values (Table I) was generally good. Overall means were 1422, 1447 , and $1510 \mu \mathrm{g} / \mathrm{g}$ for colorimetric assay of crude digests, colorimetric assay of distillates, and potentiometric assay of distillates, respectively. Correlation coefficients were calculated for the three pairs of sets in Table I; all three 
Table I. Hydrocyanic Acid Potential (HCN-p) of Dried and Ground Sorghum Leaves Determined by Colorimetric Assay of Crude Enzyme Digests and by Colorimetric and Potentiometric Assays of Distillates from Such Digests

\begin{tabular}{|c|c|c|c|c|}
\hline \multirow{3}{*}{\multicolumn{2}{|c|}{ entry ${ }^{a}$}} & \multicolumn{3}{|c|}{$\begin{array}{c}\mathrm{HCN}-\mathrm{p}^{b}(\mu \mathrm{g} / \mathrm{g} \text { dry wt) based } \\
\text { on }\end{array}$} \\
\hline & & \multirow{3}{*}{$\begin{array}{c}\text { crude } \\
\text { digest, } \\
\text { colorimetric }\end{array}$} & \multicolumn{2}{|c|}{ distillate } \\
\hline & & & colori- & potentio- \\
\hline no. & designation & & metric & metric \\
\hline 1 & KS8 & 7 & 10 & 53 \\
\hline 2 & KS8 & 30 & 25 & 64 \\
\hline 3 & $\begin{array}{l}\text { Colman } \times \text { White } \\
\text { Collier-1 }\end{array}$ & 424 & 389 & 370 \\
\hline 4 & $\begin{array}{l}\text { Colman } \times \text { White } \\
\text { Collier-2 }\end{array}$ & 691 & 657 & 683 \\
\hline 5 & Colman & 795 & 746 & 793 \\
\hline 6 & White Collier & 894 & 778 & 785 \\
\hline 7 & Redlan $\times$ Greenleaf & 380 & 355 & 343 \\
\hline 8 & Redlan $\times$ Greenleaf & 419 & 417 & 443 \\
\hline 9 & Redlan $\times$ Greenleaf & 820 & 860 & 899 \\
\hline 10 & Redlan $\times$ Greenleaf & 1883 & 1890 & 2033 \\
\hline 11 & $\mathrm{~N} 32$ & 936 & 902 & 977 \\
\hline 12 & N32 & 1109 & 1114 & 1165 \\
\hline 13 & N32 & 1235 & 1155 & 1177 \\
\hline 14 & N32 & 3884 & 3769 & 3850 \\
\hline 15 & Martin & 7828 & 8645 & 9020 \\
\hline \multicolumn{2}{|c|}{ mean } & 1422 & 1447 & 1510 \\
\hline
\end{tabular}

${ }^{\circ}$ Entries 14 and 15 are shoots from 1-week-old chamber-grown seedlings; other entries are upper leaves from field-grown plants at various stages of development. ${ }^{b}$ Values shown are means of duplicate determinations which, in most cases, were within $5 \%$ of each other.

values exceeded 0.99 . On this basis, the direct colorimetric assay of crude digests appears to be satisfactory for $\mathrm{HCN}-\mathrm{p}$ determination.

Hydrolysis with Almond Meal Compared to Hydrolysis with NaOH. Duplicate extracts of the 15 entries listed in Table I were prepared, and duplicate 1-mL portions of each extract were subjected to digestion with almond meal and colorimetric assay as described above. Also, duplicate $1-\mathrm{mL}$ portions were diluted with $9 \mathrm{~mL}$ of $0.1 \mathrm{M} \mathrm{NaOH}$, and initial and 3-h scans from 400 to $240 \mathrm{~nm}$ were done. Mao and Anderson (1965) reported that dhurrin in $0.067 \mathrm{M} \mathrm{NaOH}$ has a 21-min half-life; thus, the 3 -h treatments should effect virtually complete hydrolysis of the glucoside. Calculations of HCN-p were based on (a) colorimetric assay of the alkaline hydrolysates for cyanide and (b) gain in absorbance of the solutions at 330 $\mathrm{nm}$ during the 3-h period of hydrolysis in $\mathrm{NaOH}$.

Colorimetric assay of extracts following digestion with almond meal gave HCN-p values (Table II) that agreed well with the values shown in Table I, indicating that reproducible results were obtained with these extraction and assay procedures. Hydrolysis of the extracts with $\mathrm{NaOH}$ yielded much lower HCN-p values. This was especially true of the values based on $A_{330}$ gain; the overall mean for these assays was $774 \mu \mathrm{g} / \mathrm{g}$ compared with 1413 $\mu \mathrm{g} / \mathrm{g}$ for the colorimetric assays of enzyme-hydrolyzed extracts. Recovery of cyanide added to enzyme-hydrolyzed extracts and of cyanide and $p$-HB added to basehydrolyzed extracts exceeded $95 \%$; therefore, the lower values observed following hydrolysis with $\mathrm{NaOH}$ cannot be attributed to reduced recovery. Rather it appears that, in dilute $\mathrm{NaOH}$, dhurrin reacted with some constituent(s) of the leaf extracts in such a way that dhurrin was lost without yielding HCN or $p$-HB. Sucrose and glucose have been observed to have such an effect on dhurrin, whereas glycine does not (Haskins et al., 1984). In the present study we observed that small amounts of ethanol had an effect similar to that of glucose and sucrose. Therefore,
Table II. Hydrocyanic Acid Potential (HCN-p) of Dried and Ground Sorghum Leaves Determined by Colorimetric Assay of Enzyme- and NaOH-Hydrolyzed Extracts and by Gain in Absorbance at $330 \mathrm{~nm}$ in $\mathrm{NaOH}-\mathrm{Hydrolyzed}$ Extracts

\begin{tabular}{|c|c|c|c|}
\hline \multirow[b]{3}{*}{ entry ${ }^{a}$} & \multicolumn{3}{|c|}{ HCN-p ${ }^{b}(\mu \mathrm{g} / \mathrm{g}$ dry wt) based on } \\
\hline & \multirow{2}{*}{$\begin{array}{l}\text { enzyme digest, } \\
\text { colorimetric }\end{array}$} & \multicolumn{2}{|c|}{$\mathrm{NaOH}$ hydrolysate } \\
\hline & & colorimetric & gain in $A_{330}$ \\
\hline 1 & $10 \pm 2$ & $15 \pm 2$ & 0 \\
\hline 2 & $42 \pm 2$ & $19 \pm 1$ & $17 \pm 1$ \\
\hline 3 & $440 \pm 5$ & $129 \pm 1$ & $75 \pm 2$ \\
\hline 4 & $699 \pm 4$ & $301 \pm 3$ & $206 \pm 1$ \\
\hline 5 & $800 \pm 7$ & $284 \pm 4$ & $197 \pm 3$ \\
\hline 6 & $915 \pm 5$ & $450 \pm 2$ & $330 \pm 3$ \\
\hline 7 & $395 \pm 5$ & $110 \pm 1$ & $47 \pm 1$ \\
\hline 8 & $396 \pm 3$ & $298 \pm 3$ & $155 \pm 2$ \\
\hline 9 & $820 \pm 4$ & $442 \pm 2$ & $286 \pm 2$ \\
\hline 10 & $1851 \pm 17$ & $1085 \pm 8$ & $710 \pm 7$ \\
\hline 11 & $940 \pm 4$ & $524 \pm \pm$ & $393 \pm 1$ \\
\hline 12 & $1120 \pm 23$ & $640 \pm 7$ & $481 \pm 3$ \\
\hline 13 & $1216 \pm 10$ & $655 \pm 4$ & $486 \pm 3$ \\
\hline 14 & $3736 \pm 53$ & $2746 \pm 17$ & $2400 \pm 13$ \\
\hline 15 & $7820 \pm 39$ & $6611 \pm 64$ & $5827 \pm 13$ \\
\hline mean & 1413 & 954 & 774 \\
\hline
\end{tabular}

${ }^{a}$ See Table I for designation of entries. ${ }^{b}$ Duplicate determinations on duplicate extracts; thus, $n=4$ for each mean \pm SE.

ethanol should not be used to prepare sorghum leaf extracts that are to be subjected to alkaline hydrolysis prior to assay for cyanide.

Despite the large effects of hydrolysis and assay methods illustrated by the values in Table II, correlation coefficients between the sets of values all exceeded 0.99 . Therefore, any of the three procedures used for these assays would probably be satisfactory for ranking a group of samples representing a wide range of $\mathrm{HCN}-\mathrm{p}$. For accuracy, however, the procedure utilizing almond meal is preferable to those employing alkali to hydrolyze dhurrin.

Other Precautions. To determine whether capping the test tubes during enzymatic hydrolysis of dhurrin was beneficial, 1-mL portions of six different sorghum leaf extracts were digested with 1-mL portions of almond meal extract in capped tubes as described in Materials and Methods, and six comparable tubes were left uncapped during digestion. Colorimetric assays yielded values for the uncapped digests that were $85-89 \%$ as high as those obtained for the capped digests. Evidently the Parafilm caps were effective in reducing loss of HCN during the digestion step.

Solutions of $\mathrm{KCN}$ and $\mathrm{NaCN}$ are stable at room temperature for at least 1 week, and this was also found to be true of the cyanide in distillates from sorghum leaf digests. However, when almond meal digests of sorghum leaf extracts were diluted with $\mathrm{NaOH}$ and allowed to stand at room temperature for 1 or 3 days before the colorimetric assay was done, losses in $\mathrm{HCN}$-p were as high as 25 and $50 \%$, respectively. Therefore, it is important to proceed with the colorimetric assay as soon as possible after the digests have been diluted with $\mathrm{NaOH}$.

In the potentiometric assay described in Materials and Methods, the extra water for distillation should be added following the digestion, as indicated. When $50 \mathrm{~mL}$ of tissue extract was diluted to $400 \mathrm{~mL}$ prior to introduction of the enzyme preparation, the HCN-p values obtained were about $80-85 \%$ as high as those based on dilution following digestion.

Suitability of the Procedure for Large Numbers of Samples. Starting with dried and ground plant samples, a skilled technician can conveniently accomplish the required weighing, extraction, digestion, and colorimetric 
determination on 70-80 samples per day. Thus, the described procedure combining enzymatic hydrolysis and colorimetric assay is suitable for research projects that generate substantial numbers of samples.

\section{ABBREVIATIONS USED}

$\mathrm{HCN}-\mathrm{p}$, hydrocyanic acid potential; $p$-HB, $p$-hydroxybenzaldehyde.

\section{ACKNOWLEDGMENT}

The excellent technical assistance of Carol Caha and John Toy is gratefully acknowledged.

Registry No. $\mathrm{CN}^{-}$, 57-12-5; dhurrin, 499-20-7.

\section{LITERATURE CITED}

Association of Official Agricultural Chemists Methods of Analysis, 6th ed.; AOAC: Washington, DC, 1945; p 416.

Blaedel, W. J.; Easty, D. B.; Anderson, L.; Farrell, T. R. "Potentiometric Determination of Cyanide with an Ion Selective Electrode: Application to Cyanogenic Glycosides in Sudan Grasses". Anal. Chem. 1971, 43, 890-894.

Easty, D. B.; Blaedel, W. J.; Anderson, L. "Continuous Electrochemical Determination of Cyanide: Application to Cyanogenic Glycosides in Sudan Grass". Anal. Chem. 1971, 43, 509-514.

Gorz, H. J.; Haag, W. L.; Specht, J. E.; Haskins, F. A. "Assay of $p$-Hydroxybenzaldehyde as a Measure of Hydrocyanic Acid
Potential in Sorghums". Crop Sci. 1977, 17, 578-582.

Gorz, H. J.; Haskins, F. A.; Vogel, K. P. "Inheritance of Dhurrin Content in Mature Sorghum Leaves". Crop Sci. 1986, 26, 65-67.

Haskins, F. A.; Gorz, H. J.; Hill, R. M.; Youngquist, J. B. "Influence of Sample Treatment on Apparent Hydrocyanic Acid Potential of Sorghum Leaf Tissue". Crop Sci. 1984, 24, 1158-1163.

Lambert, J. L.; Ramasamy, J.; Paukstelis, J. V. "Stable Reagents for the Colorimetric Determination of Cyanide by Modified König Reactions”. Anal. Chem. 1975, 47, 916-918.

Mao, C.-H.; Anderson, L. "Cyanogenesis in Sorghum vulgare. 2. Mechanism of the Alkaline Hydrolysis of Dhurrin ( $p$ Hydroxymandelonitrile Glucoside)". J. Org. Chem. 1965, 30, 603-607.

Ross, W. M.; Gorz, H. J.; Haskins, F. A.; Webster, O. J. "Registration of Ten Sorghum Parental Lines (Reg. No. PL49 to PL58)". Crop Sci. 1980, $20,834$.

Received for review September 22, 1987. Accepted March 29, 1988. Contribution from the USDA-ARS and the Departments of Agronomy and Biochemistry, Nebraska Agricultural Research Division. Published as Paper No. 8435, Journal Series, Nebraska Agricultural Research Division. Reference to a company or product name does not imply approval or recommendation of the product by the USDA or the University of Nebraska to the exclusion of others that may be suitable. 